UDC 697.34:681.518

DOI: $10.15587 / 2706-5448.2021 .240263$

Article type «Original research»

\section{Yevheniia Chehotarova, Andrii Perekrest}

\title{
MODERNIZATION OF ELECTRICAL COMPLEX FOR PRODUCING THERMAL ENERGY FOR AN INDUSTRIAL ENTERPRISE
}

The object of research is the electrical complex for the preparation of thermal energy at the enterprise. The electrotechnical complex is a heat supply unit that provides thermal energy to the building of the enterprise for the needs of heating, ventilation and hot water supply. One of the identified shortcomings of this facility is the overconsumption of energy resources for heating, caused by the lack of the ability to control consumption. Modernization of heat points and equipping them with automation means will provide quantitative and qualitative control of the heat carrier depending on the outside air temperature.

In the course of the study, the method of statistical data analysis was used to analyze the heat load of buildings for heating, ventilation and hot water supply, and the distribution of heat loads by the temperature of the indoor air. Also, an improved discounted method for evaluating the effectiveness of investment projects was used when calculating economic indicators and a method for calculating heat consumption for heating according to aggregated indicators when determining energy consumption for heating.

On the basis of the analysis of the heat load and a certain structure of its distribution according to the temperature of the internal air, it was found that more energy resources are consumed for heating. The largest consumer is defined as a building with an internal temperature $T_{\text {in }}=16^{\circ} \mathrm{C}$. Calculations of the commercial attractiveness of the proposed technical solutions for buildings with an internal temperature $T_{\text {in }}=18{ }^{\circ} \mathrm{C}$ have confirmed the feasibility of their implementation in terms of their payback, which does not exceed the period of 3.5 heated seasons.

Thanks to the modernization of heat points and the introduction of automated monitoring and regulation systems, optimal heat energy consumption will be ensured depending on the ambient temperature. Unlike other similar studies, the feasibility of introducing automated systems is determined by an improved discounted method, which allows not only to take into account the change in the value of money in the future, but also the required minimum percentage of thermal energy savings to break even projects.

Keywords: automation of heating units, load distribution, electrical complex, energy demand, efficiency assessment, discounted method.

Chebotarova, Y., Perekrest, A. (2021). Modernization of electrical complex for producing thermal energy for an industrial enterprise. Technology Audit and Production Reserves, 5 (1 (61)), 25-32. doi: http://doi.org/10.15587/2706-5448.2021.240263

\section{Introduction}

One of the urgent problems is the constant increase in the consumption of fuel and energy resources. According to the International Energy Agency, the level of world energy consumption in the period 2010-2035 will grow by another $35 \%$. It is possible to reduce their use by increasing the efficiency of the use of energy resources in all sectors of the economy, primarily the most energyintensive - industry and energy. In the last 10 years alone, the energy intensity of GDP:

- the member countries of the Organization for Economic Cooperation and Development has been reduced from 0.16 tons of oil equivalent (t. o. e.) per 1000 USD to $0.14(-12.5 \%)$;
- member states of the European Union - from 0.14 to $0.12(-14.2 \%)$;

- the world as a whole - from 0.191 to $0.186(-2.6 \%)$ [1].

Let's consider this issue in more detail using the example of Ukraine. In Ukraine, there remains an extremely high level of energy intensity (according to the State Statistics Service of Ukraine in 2017 it amounted to 0.27 t. o. e./thousand GDP) [2] and a low level of efficiency in the use of energy resources. For comparison, in Belarus the energy intensity in 2017 is 0.16 , Slovenia and Hungary - 0.11, Poland - 0.1. Most of the enterprises in Ukraine were founded in Soviet times and own a fund of buildings with morally and technically outdated engineering systems and equipment. The unsatisfactory state of the art of engineering systems, the lack of monitoring, control and regulation 
leads to overspending of the energy and financial resources of the enterprise. As a result, the cost of its products rises, which significantly reduces its competitiveness in the international market.

Ensuring the proper functioning of large volumes of industrial buildings and reducing the cost of their maintenance is possible through thermal modernization and/or the use of alternative energy sources. The modernization of enterprise buildings is a complex, multi-stage and timeconsuming process, since due to the abundance of facilities, it is impossible to simultaneously carry out work on all facilities. Therefore, the primary task is to prioritize modernization by conducting a preliminary analysis of facilities, determining the distribution of heat load for heating, ventilation and hot water supply between them. For the selected objects, a technical solution is selected and the economic feasibility of its implementation is assessed.

\section{The object of research and its technological audit}

The object of research is an electrical complex for the preparation of thermal energy. The electrical complex is a heating unit that provides thermal energy to the building of the enterprise. The company has 226 buildings, of which 168 are with heating load, 70 with ventilation load, 214 with heating-ventilation load. The distribution of the total number of buildings by subordination is given in Table 1.

Table 1

List of workshops, total number and volume of buildings

\begin{tabular}{|c|c|c|c|c|}
\hline $\begin{array}{c}\text { Subordi- } \\
\text { nation }\end{array}$ & $\begin{array}{c}\text { Number of } \\
\text { buildings }\end{array}$ & $\begin{array}{c}\text { Number of } \\
\text { heated buildings }\end{array}$ & $\begin{array}{c}\text { Total } \\
\text { volume, } \mathrm{m}^{3}\end{array}$ & $\begin{array}{c}\text { Total volume } \\
\text { of heated build- } \\
\text { ings, } \mathrm{m}^{3}\end{array}$ \\
\hline 1 & 2 & 2 & 16237 & 16237 \\
\hline 2 & 3 & 3 & 60922 & 60922 \\
\hline 3 & 1 & 1 & 8241 & 8241 \\
\hline 4 & 17 & 14 & 379593 & 369952 \\
\hline 5 & 23 & 15 & 80315 & 60680 \\
\hline 6 & 16 & 4 & 56328 & 45446 \\
\hline 7 & 22 & 21 & 1519781 & 1504180.5 \\
\hline 8 & 5 & 5 & 5000 & 5000 \\
\hline 9 & 22 & 14 & 101080 & 89268 \\
\hline 10 & 18 & 10 & 218214 & 181771 \\
\hline 11 & 9 & 6 & 238427 & 237727 \\
\hline 12 & 10 & 10 & 127331 & 127331 \\
\hline 13 & 8 & 8 & 593188 & 593188 \\
\hline 14 & 8 & 8 & 13428 & 13428 \\
\hline 15 & 8 & 3 & 16527 & 15214 \\
\hline 16 & 7 & 0 & 2728 & 0 \\
\hline 17 & 11 & 5 & 22686 & 8158 \\
\hline 18 & 6 & 0 & 7000 & 0 \\
\hline 19 & 30 & 11 & 147204 & 106994 \\
\hline Total & $\mathbf{2 2 6}$ & $\mathbf{1 4 0}$ & $\mathbf{3 6 1 4 2 3 0}$ & $\mathbf{3 4 4 3 7 3 7 . 5}$ \\
\hline
\end{tabular}

One of the identified shortcomings of this facility is the overusing of energy resources caused by the overheating and insufficient heating of buildings and the lack of the ability to manage consumption.

\section{The aim and objectives of research}

The aim of research is to substantiate the need to reequip heating units of individual objects of an industrial enterprise.

To achieve this aim, the following objectives were set:

1. To carry out an analysis of the heat load for heating, ventilation and hot water supply (HWS), and carry out its distribution according to the internal temperature in the room.

2. To determine the energy consumption of buildings for heating.

3. To propose a scheme of an automated individual heating point with monitoring and control of heat consumption and to determine the economic efficiency of the proposed technical solution.

\section{Research of existing solutions to the problem}

An important issue in the efficiency of district heating systems is the large difference between energy consumption and actual energy consumption. This difference is especially noticeable at industrial facilities. Indeed, many enterprises still use outdated equipment, and large volumes of heated area and not insulated enclosing structures only increase the already excessive consumption of energy resources. A large number of works have been devoted to the issues of modernization of heat points (HP) and increasing the efficiency of using thermal energy for heating. For example, in works [3, 4], methods of improving district heating systems by upgrading HP and heating networks are considered. The advantages of an automated individual heating point (AIHP) over centralized heating have been determined, based on the factors influencing the heating system, heat savings are calculated when installing AIHP. The study [5] presents the use of devices such as frequency converters, high efficiency electronic pumps, electronic controls, thermostatic valves, which are integral parts of one thermal substation. The analysis of the thermal substation was carried out before and after the implementation of energy efficiency measures. In [6], it is proposed to introduce air-to-water heat pumps into existing district heating systems to supply heat in the industrial sector. The authors present a thematic analysis of the effective integration of a $25 \mathrm{~kW}$ heat pump into an industrial heat supply substation. Research results show that a heat pump is only effective for industrial practice if there is a positive return on investment. Improving the efficiency of heating systems supplying cities of the Republic of Tatarstan is presented in [7]. The authors obtained dependencies that make it possible to estimate the required pressure difference from the heat supply source, depending on the nominal pressure difference at the nodal points of the system (the area of the heat substation) when the AIHP is introduced. These dependencies were obtained by comparing the actual values of the operating parameters obtained according to the indicators of the installed metering device in the heat supply system with the results obtained by mathematical modeling of the heat supply system and data obtained as a result of laboratory experiments. In [8], a new alternative control approach is proposed for indirectly connected district heating substations. The idea behind the new control method is to consider the temperature of the water supplied by the district heating substa- 
tion, often referred to as the primary supply temperature. In combination with modeling, the authors have developed a control optimization methodology based on a physical model. This paper shows how primary flow temperature, together with thermodynamic knowledge of a building, can be used to maximize $\Delta T$ in a district heating substation.

In contrast to the aforementioned works, in [9] the author proposes replacing district heating with low temperature district heating (LTDH), which can provide a better match between supply and demand in terms of energy quality and quantity. The paper analyzes the energy and exergy of the LTDH substation, which supplies the LTDH secondary network as a sub-network of the existing district heating system. The results show that the proposed substation reduced the share of annual energy demand by $20-25 \%$.

Separately, the issues of determining the normal and abnormal characteristics of the heat load at consumer substations are considered as ways to optimize energy consumption [10,11]. Thus, in [10], one year of hourly readings of heat meters from 141 substations in two district heating networks were analyzed.

Thus, the results of the analysis allow concluding that the modernization of the existing district heating system significantly reduces the consumption of energy resources. The most common modernization method is the introduction of individual heating points. Therefore, as a technical solution in the future, the scheme of an automated individual heating point will be considered proposed in [12] and the economic and energy feasibility of its implementation will be determined.

\section{Methods of research}

The following methods and techniques were used in the study:

- method of statistical data analysis - in the analysis of heat load of buildings for heating, ventilation and hot water supply, and the distribution of heat loads by indoor air temperature;

- improved discounted method for assessing the effectiveness of investment projects - when calculating economic indicators;

- method of calculating heat consumption for heating according to the consolidated indicators.

\section{Research results}

The distribution of the number of buildings according to subordination depending on the type of heat loads: heating $(\mathrm{H})$, ventilation $(\mathrm{V})$, hot water supply (HWS), Table 2.

Fig. 1 shows the general distribution of the number and heat load of buildings by temperature in the middle of the room.

In Fig. 2 the following designations are adopted: 1 - buildings with $T_{i n}=18{ }^{\circ} \mathrm{C} ; 2$ - buildings with heating and $T_{i n}=18{ }^{\circ} \mathrm{C} ; 3$ - buildings with $T_{i n}=16{ }^{\circ} \mathrm{C} ; 4$ - buildings with heating and $T_{i n}=16{ }^{\circ} \mathrm{C} ; 5-$ buildings with $T_{i n}=10^{\circ} \mathrm{C}$; 6 - buildings with heating and $T_{i n}=10{ }^{\circ} \mathrm{C} ; 7$ - buildings with $T_{i n}=5{ }^{\circ} \mathrm{C} ; 8$ - buildings with heating and $T_{i n}=5{ }^{\circ} \mathrm{C}$.

Fig. 3 shows a diagram of the load distribution in $\mathrm{Gcal} / \mathrm{h}$ of buildings by indoor air temperature $T_{i n}$. For the selected buildings, a bar chart of the distribution of their number and loads by indoor air temperatures is constructed (Fig. 4).
Table 2

Heat loads of buildings for heating, ventilation and hot water supply

\begin{tabular}{|c|c|c|c|c|c|c|c|c|}
\hline \multirow{2}{*}{$\begin{array}{c}\text { Subor- } \\
\text { dina- } \\
\text { tion }\end{array}$} & \multicolumn{7}{|c|}{ Load type } \\
\cline { 2 - 9 } & Gcal & $\begin{array}{c}\text { Num- } \\
\text { ber }\end{array}$ & Gcal & $\begin{array}{c}\text { Num- } \\
\text { ber }\end{array}$ & Gcal & $\begin{array}{c}\text { Num- } \\
\text { ber }\end{array}$ & Gcal & $\begin{array}{c}\text { Num- } \\
\text { ber }\end{array}$ \\
\hline 1 & 0.258 & 2 & 0 & 0 & 0.258 & 2 & 0.328 & 2 \\
\hline 2 & 0.650 & 3 & 0 & 0 & 0.65 & 3 & 0.10 & 1 \\
\hline 3 & 0.017 & 1 & 0.00 & 0 & 0.017 & 1 & 0.00 & 0 \\
\hline 4 & 3.753 & 15 & 3.87 & 8 & 7.624 & 23 & 0.19 & 2 \\
\hline 5 & 1.727 & 15 & 0.46 & 5 & 2.402 & 20 & 0.22 & 3 \\
\hline 6 & 0.830 & 15 & 0.14 & 12 & 0.965 & 27 & 0.15 & 3 \\
\hline 7 & 12.437 & 22 & 12.57 & 10 & 24.406 & 32 & 0.28 & 4 \\
\hline 8 & 0.072 & 5 & 0.00 & 0 & 0.072 & 5 & 0.02 & 1 \\
\hline 9 & 2.226 & 20 & 1.57 & 2 & 3.688 & 22 & 0.49 & 4 \\
\hline 10 & 3.181 & 18 & 1.26 & 1 & 4.441 & 19 & 0.00 & 0 \\
\hline 11 & 2.455 & 6 & 2.46 & 6 & 4.911 & 12 & 0.27 & 1 \\
\hline 12 & 1.399 & 10 & 0.62 & 4 & 2.015 & 14 & 0.38 & 2 \\
\hline 13 & 11.289 & 8 & 8.69 & 8 & 20.974 & 16 & 0.00 & 0 \\
\hline 14 & 0.161 & 8 & 0.01 & 1 & 0.165 & 9 & 0.04 & 1 \\
\hline 15 & 0.277 & 8 & 0.00 & 0 & 0.277 & 8 & 0.07 & 1 \\
\hline 16 & 0.054 & 6 & 0.04 & 2 & 0.092 & 8 & 0.04 & 1 \\
\hline 17 & 0.359 & 11 & 0.29 & 6 & 0.652 & 17 & 0.21 & 3 \\
\hline 18 & 0.571 & 6 & 0.00 & 0 & 0.571 & 6 & 0.02 & 1 \\
\hline 19 & 2.062 & 27 & 0.87 & 4 & 3.006 & 31 & 0.14 & 3 \\
\hline Total & $\mathbf{4 3 . 7 7 8}$ & $\mathbf{2 0 6}$ & $\mathbf{3 2 . 8 3 7}$ & $\mathbf{6 9}$ & $\mathbf{7 7 . 1 8 6}$ & $\mathbf{2 7 5}$ & $\mathbf{2 . 9 3 8}$ & $\mathbf{3 3}$ \\
\hline & & & & & & \\
\hline
\end{tabular}

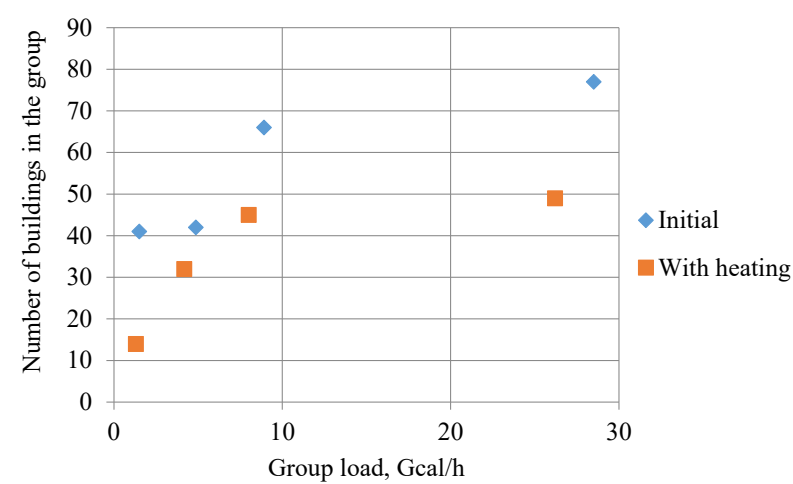

Fig. 1. General distribution of quantity and heat load depending on the temperature of the indoor air

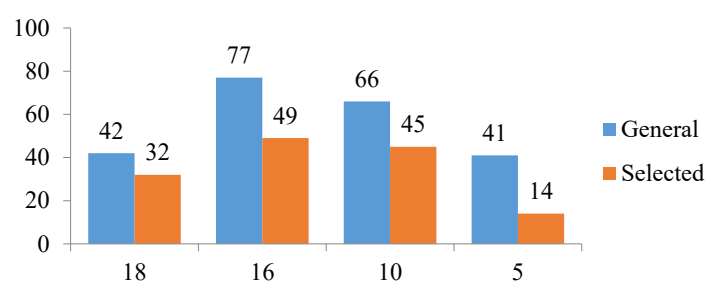

Fig. 2. Comparison of the number of initial and selected buildings

Analysis of the above data (Fig. 3, 4) shows that the largest consumers of thermal energy are buildings with $T_{i n}=16^{\circ} \mathrm{C}-$ 49 buildings with a load of $26.2 \mathrm{Gcal} / \mathrm{h}(66.1 \%)$, then 45 buildings with $T_{\text {in }}=10{ }^{\circ} \mathrm{C}-7.9975 \mathrm{Gcal} / \mathrm{h}(20.2 \%)$. 
Thirty-two office buildings with $T_{i n}=18{ }^{\circ} \mathrm{C}$ will require the third largest heat load (10.5\%). The heat load of 14 buildings with $T_{\text {in }}=5{ }^{\circ} \mathrm{C}$ is only $3.3 \%$ of the total. At the same time, it is assumed that 140 of 226 buildings will use thermal energy for heating a centralized source, which gives a decrease in the established maximum load by $9.4 \%$ from $43.7775 \mathrm{Gcal} / \mathrm{h}$ to $39.6525 \mathrm{Gcal} / \mathrm{h}$.

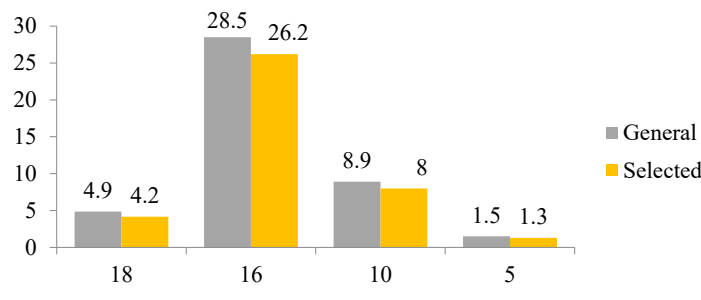

Fig. 3. Comparison of building loads by indoor air temperatures

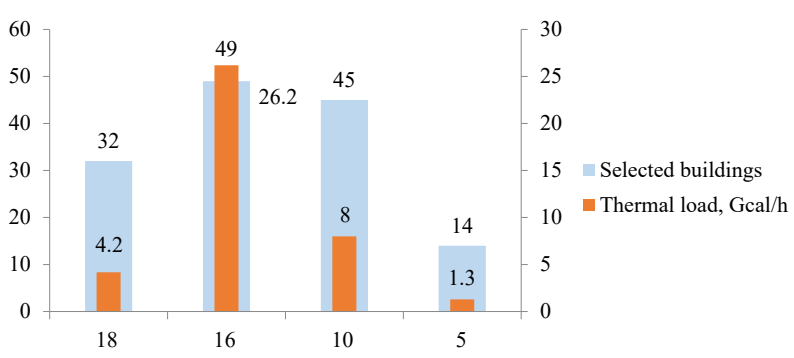

Fig. 4. Distribution of the number and loads of the selected buildings by indoor air temperatures

The statistics of heat production for heat supply of buildings of the enterprise are given in Table 3 and Fig. 5-7.

Table 3

Statistics of heat production for heat supply of buildings of the enterprise for 2012-2016

\begin{tabular}{|c|c|c|c|c|c|}
\hline Month Year & 2012 & 2013 & 2014 & 2015 & 2016 \\
\hline January & 19927 & 17672 & 21857 & 16847 & 21699 \\
\hline February & 25175 & 12956 & 14678 & 14263 & 10866 \\
\hline March & 13484 & 14135 & 8277 & 7440 & 8723 \\
\hline April & 1394 & 1502 & 1361 & 1898 & 853 \\
\hline October & 0 & 4150 & 0 & 2980 & 4736 \\
\hline November & 7905 & 8383 & 8228 & 7670 & 11407 \\
\hline December & 17672 & 16952 & 15429 & 12343 & $12343 *$ \\
\hline Total, Gcal & 85557 & 75750 & 69830 & 63441 & 72643 \\
\hline \multicolumn{5}{|c|}{ Average for 2012-2016 } & 73444.2 \\
\hline \multicolumn{6}{|c|}{ Calculated for 140 buildings } \\
\hline
\end{tabular}

Note: * - adopted at the level of December 2015

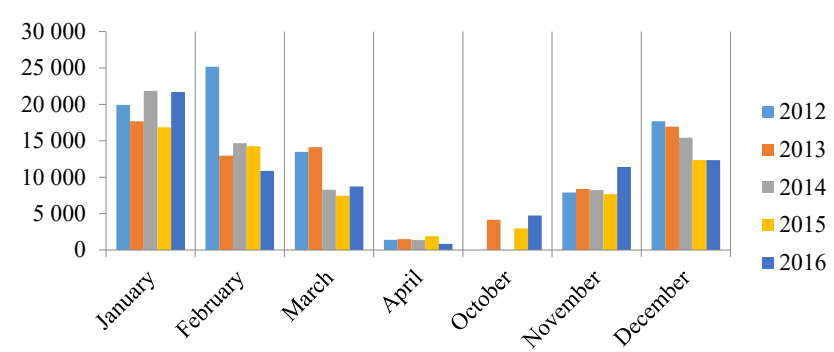

Fig. 5. Heat production by months in 2012-2016, Gcal

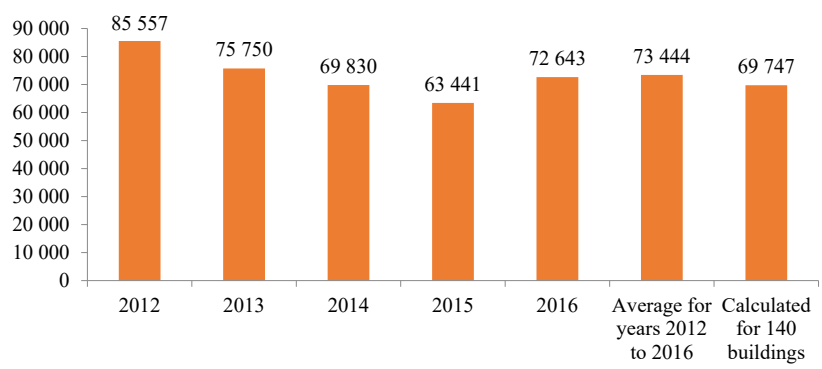

Fig. 6. Comparison of summer and average heat production and estimated annual heat consumption for 140 buildings, Gcal

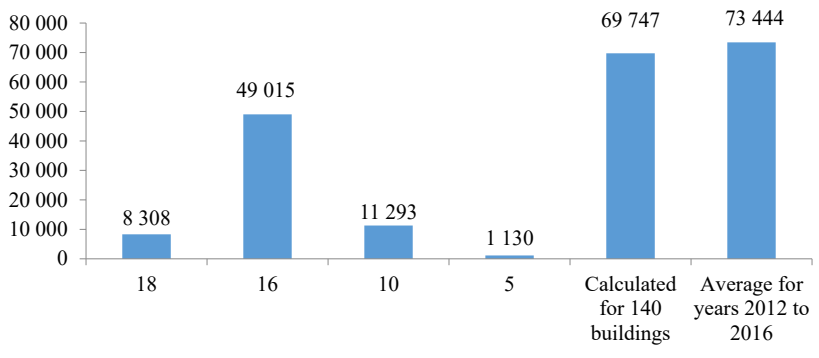

Fig. 7. Thermal loads of buildings (Gcal/h) for indoor air temperatures, calculated annual heat consumption for 140 buildings and average heat production for 2012-2016, Gcal

The greatest heat load, $55 \%$ of the total load, falls on heating (Fig. 8). To determine the energy demand for heating, the calculation of the maximum time consumption of heat was carried out for three administrative buildings of the enterprise (AB1, AB2, AB3) and one mechanical repair workshop (W1) according to enlarged indicators and DSTU-N B A.2.2-5:2007. All objects have water heating and connected to the central water supply system.

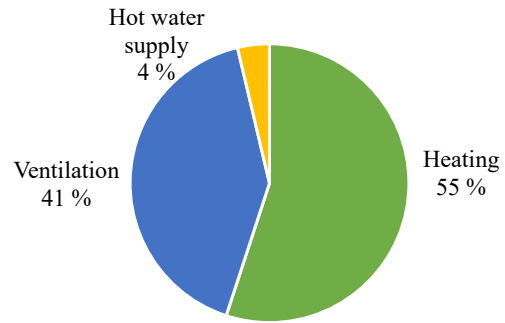

Fig. 8. Load distribution between engineering systems of buildings for heating according to the consolidated indicators

The calculation of the maximum hourly heat consumption for heating, according to aggregated indicators, is determined by the formula:

$$
Q_{\text {max }}=a \cdot q_{s} \cdot V\left(T_{\text {in }}-T_{\text {out }}\right),
$$

where $a$ - coefficient that takes into account the change in the specific thermal characteristics of the building depending on climatic conditions (outside air temperature); $q_{s}-$ specific thermal characteristic of the building, $\mathrm{kcal} /\left(\mathrm{m}^{3} \cdot \mathrm{h} \cdot{ }^{\circ} \mathrm{C}\right)$; $V$ - external volume of the building, $\mathrm{m}^{3} ; T_{i n}$ - calculated temperature in the premises of the building, ${ }^{\circ} \mathrm{C}$; $T_{\text {out }}-\mathrm{cal}-$ culated temperature of the outside air, ${ }^{\circ} \mathrm{C}$.

Annual heat consumption for heating during the heating period is determined by the formula:

$$
Q_{0}^{h}=Q_{0 \max } \cdot \frac{\left(T_{\text {in }}-T_{m}\right)}{\left(T_{\text {in }}-T_{\text {out }}\right)} \cdot 24 \cdot Z_{0} \cdot 10^{-6} \frac{-b \pm \sqrt{b^{2}-4 a c}}{2 a},
$$


where $T_{m}$ - average outside air temperature for the billing period; $Z_{0}$ - duration of the heating system operation for the billing period, days.

Hourly heat consumption for heating, according to aggregated indicators, for the building $\mathrm{AB} 1$ is:

$$
\begin{aligned}
& Q_{0 \max }=1.17 \cdot 0.41 \cdot 8467 \cdot(16-(-22))= \\
& =154341.556 \mathrm{ccal} / \mathrm{h}=0.15434 \mathrm{Gcal} / \mathrm{h} .
\end{aligned}
$$

Annual heat consumption for heating for the heating period for building $\mathrm{AB} 1$ is:

$$
\begin{aligned}
& Q_{0}^{h}=154341.5562 \cdot \frac{(16-(-0.46))}{(16-(-22))} \cdot 24 \cdot 180 \cdot 10^{-6}= \\
& =288.8127 \mathrm{Gcal} .
\end{aligned}
$$

The calculated values for all buildings are presented in Table 4

Table 5 shows the data of calculations of energy consumption for heating selected buildings according to aggregated indicators and a detailed methodology (DSTU-N B A.2.2-5:2007). Data analysis of Table 5 shows that for the building AB1, the hourly consumption of thermal energy for the expanded methodology is much less than the costs calculated according to the aggregated indicators. This is due to the fact that increases in the reduced resistance to heat transfer of external opaque wall enclosing structures with a sandwich panel $150 \mathrm{~mm}$ thick insulation is additionally taken into account. For the building M1, according to the readings of the heat meter, a significant excess consumption $(428 \mathrm{Gcal})$ of heat energy for heating was established against the calculated value (321 Gcal). For the building AB3, the energy requirements were calculated to ensure the temperature of $16{ }^{\circ} \mathrm{C}$ and $12{ }^{\circ} \mathrm{C}$ of the internal air. According to the readings of the heat meter, the calculated heat consumption is significantly lower. At the same time, according to the results of instrumental examination, the internal air temperature did not exceed $12{ }^{\circ} \mathrm{C}$.

Modernization of HP allows solving the following management tasks:

- control of the temperature of the coolant supplied to the heating system depending on the outside air temperature;

- control of the temperature of the coolant returned to the heating network, in accordance with the temperature of the outside air according to a given temperature schedule; - correction of the heat consumption mode according to the indoor air temperature;

- limiting the temperature of the coolant in the supply pipeline.

The scheme shown in Fig. 9 is used as a basic option, re-equipment of heating units of buildings [12].

In Fig. 9 the following elements of the schematic diagram are conventionally indicated:

- 1.1 - flanged ball valve DN80 (Germany);

- 1.2 - filter (Germany);

- 1.3 - ball valve DN15 (Germany);

- 1.4 - electric contact pressure gauge (Ukraine);

- 1.5 - solenoid valve DN80 (Germany);

- 1.6 - heat meter (Germany);

- 1.7 - valve with electric drive (Switzerland);

- 1.8 - thermomanometer (Ukraine);

- 1.9 - TJA (transonic jet apparatus) D89 (Great Britain);

- 1.10 - ball valve DN40 (Germany);

- 1.11 - check valve DN40 (Germany);

- 1.12 - mixing pump (Italy);

- 1.13 - circulation pump (Italy);

- 1.14 - safety bypass valve (Germany);

- 1.15 - control cabinet with controller (Ukraine,

\begin{tabular}{|c|c|c|c|c|c|c|c|c|c|}
\hline Building & $V$ & $\square_{\mathrm{s}}$ & $a$ & $T_{\text {in }}$ & $T_{\text {out }}$ & $T_{m}$ & $Z_{0}$ & $\square_{0 \max }$ & $\square_{0}^{h}$ \\
\hline $\mathrm{AB1}$ & 8467 & 0.41 & \multirow{5}{*}{1.17} & 16 & \multirow{5}{*}{-22} & \multirow{5}{*}{-0.46} & \multirow{5}{*}{180} & 0.15434 & 288.8127 \\
\hline $\mathrm{AB} 2$ & 14688 & 0.37 & & 18 & & & & 0.25433 & 507.0526 \\
\hline \multirow{2}{*}{ AB3 } & \multirow{2}{*}{27216} & \multirow{2}{*}{0.36} & & 16 & & & & 0.43561 & 815.1357 \\
\hline & & & & 12 & & & & 0.38975 & 617.0329 \\
\hline W1 & 7851 & 0.41 & & 18 & & & & 0.15064 & 300.3279 \\
\hline
\end{tabular}
Switzerland).

Calculation data for aggregated indicators

Table 4

Hourly and annual heating costs of buildings

Table 5

\begin{tabular}{|c|c|c|c|c|c|}
\hline \multirow{2}{*}{ Buildings } & \multicolumn{2}{|c|}{ Hourly expenses, Gcal/h } & \multicolumn{3}{c|}{ Annual expenses, Gcal } \\
\cline { 2 - 6 } & $\begin{array}{c}\text { according to the aggregated } \\
\text { indicators }\end{array}$ & $\begin{array}{c}\text { according to } \\
\text { DSTU-N B A.2.2-5:2007 }\end{array}$ & $\begin{array}{c}\text { according to the aggregated } \\
\text { indicators }\end{array}$ & $\begin{array}{c}\text { according to } \\
\text { DSTU-N B A.2.2-5:2007 }\end{array}$ & $\begin{array}{c}\text { according to } \\
\text { counters }\end{array}$ \\
\hline AB2 & 0.25433 & 0.359389 & 507.0526 & 672.5072 & - \\
\hline AB1 (insulated) & 0.15434 & 0.08969 & 288.8127 & 178.8139 & - \\
\hline AB3 (at $T_{\text {in }}=16^{\circ}$ ') & 0.43561 & 0.685057 & 815.1357 & 1281.914 & 293 \\
\hline AB3 (at $T_{\text {in }}=12^{\circ}$ C) & 0.38975 & 0.809723 & 617.0329 & 1140.8 & - \\
\hline W1 & 0.15064 & 0.163786 & 300.3279 & 326.5362 & 428.0835 \\
\hline
\end{tabular}




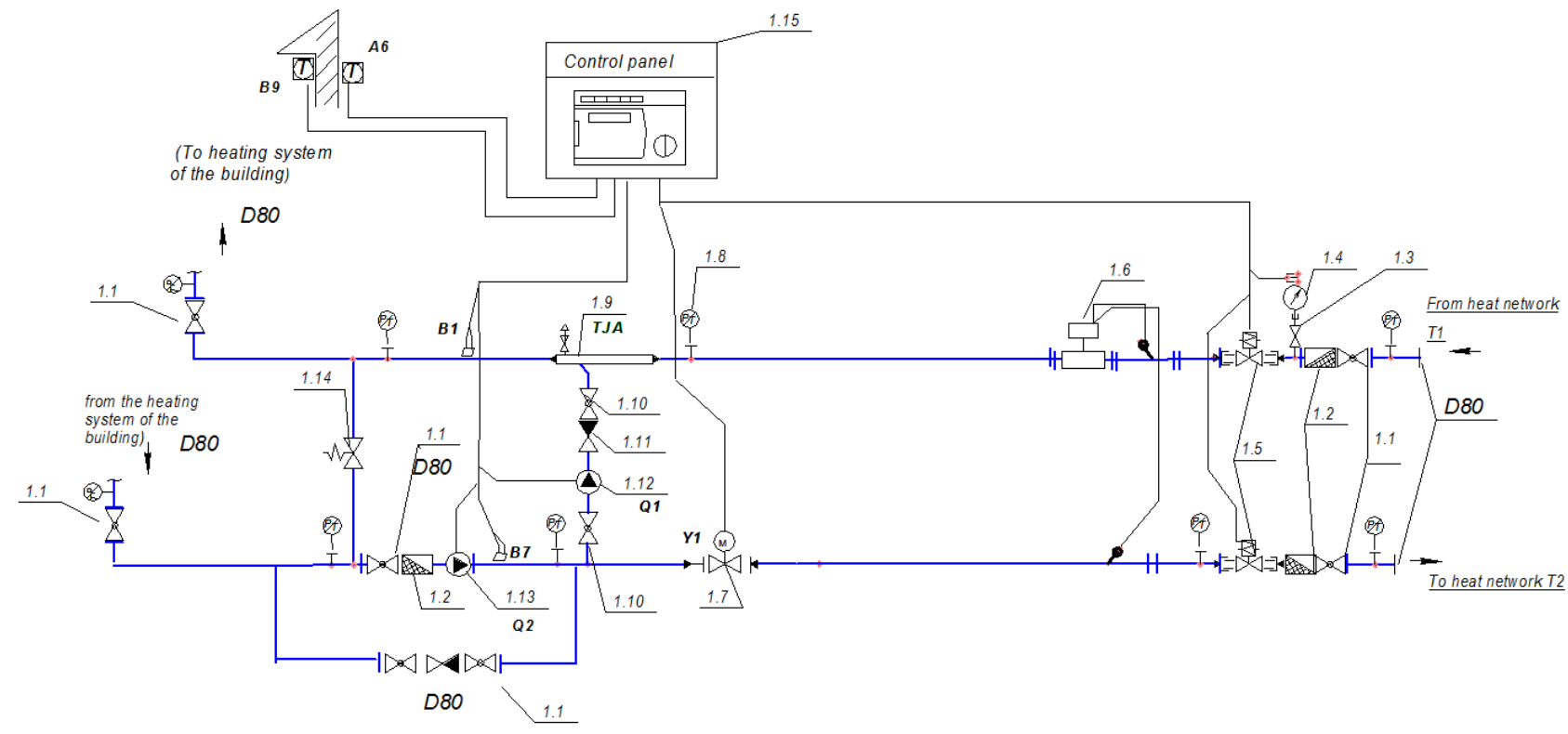

Fig. 9. Schematic diagram of the improved heating unit $A B 3$

The 1.12 pump performs the function of a mixing device, and the 1.13 pump is used to improve the hydraulic and thermal characteristics of the modes in the extreme branches of the thermal system. Weather-compensated control is carried out using an electric valve, temperature sensors and an electronic controller. The local control system consists of a thermomanometer, heat meter, electro-contact manometer, temperature sensors and provides control of the main parameters and equipment control. An automated individual heating station is controlled from a control cabinet, which consists of a controller and power supply protection and control of power units and automation.

In addition, an automated monitoring and control system (AMCS) (Fig. 10) is proposed, which monitors technological processes and management of engineering systems and provides information on their status in real time.

To assess the economic efficiency of the proposed technical solution, an improved discounted method of assessing efficiency was chosen [13]. The main advantages of this method are that it takes into account the change in the value of money over time, and additional accounting for the break-even criterion allows ranking buildings according to the priority of their modernization based on investment attractiveness. Calculations of economic indicators were carried out using self-developed software (Fig. 11) [14], which is a subroutine of the expert system for assessing the effectiveness of various energy-saving solutions, implemented in the building.

When calculating the baseline consumption in thousand cubic meters of natural gas, a coefficient of 0.126 is taken. Operating costs take into account the cost of electricity for the operation of electrical equipment of heating units, personnel salaries, depreciation deductions, which are $10 \%$ of the cost of equipment, and repair and maintenance of the installation in the amount of $3 \%$ of the cost of equipment. Table 6 summarizes the initial data for calculating the technical and economic indicators of four selected buildings.

Various values of the discount rate are used as factors influencing the efficiency of projects: $r=0.1$ - the company's own funds; $r=0.15$ - current discount rate of the National Bank of Ukraine; $r=0.25$ - the event is financed by attracting borrowed funds.

For individual consumers, taking into account their heat consumption, the general indicators of the economic efficiency of the implementation of the proposed technical solutions for 22 buildings of the enterprise were calculated for $T_{\text {in }}=18{ }^{\circ} \mathrm{C}$ (Table 7 ). Their total heat consumption is $7701.4 \mathrm{Gcal}$.

Projects are divided into three groups with a cost of 4.9 ; 8 and 10.4 thousand USD for buildings with varying heat loads and demand. Projects worth 4.9 thousand USD acceptable for buildings with annual heat consumption from 124.4 to $305.8 \mathrm{Gcal}$, projects for 8 thousand USD - from 476.9 to $672.5 \mathrm{Gcal}$, project for 10.4 thousand USD - for a building with 855.3 Gcal.

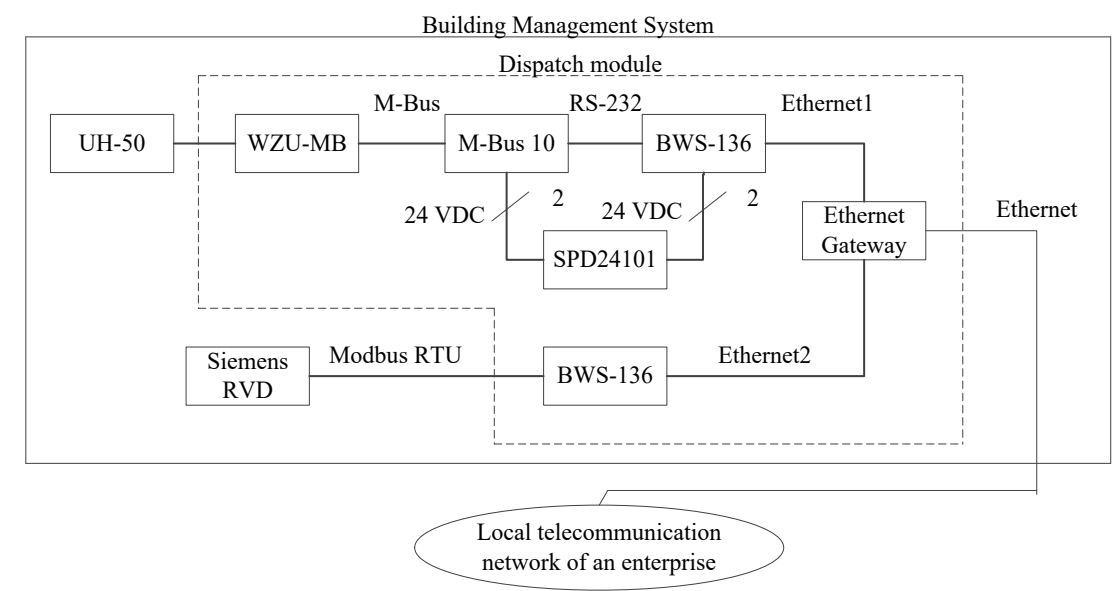

Fig. 10. Functional diagram of an automated system for monitoring temperature conditions and remote control of heat consumption in buildings 


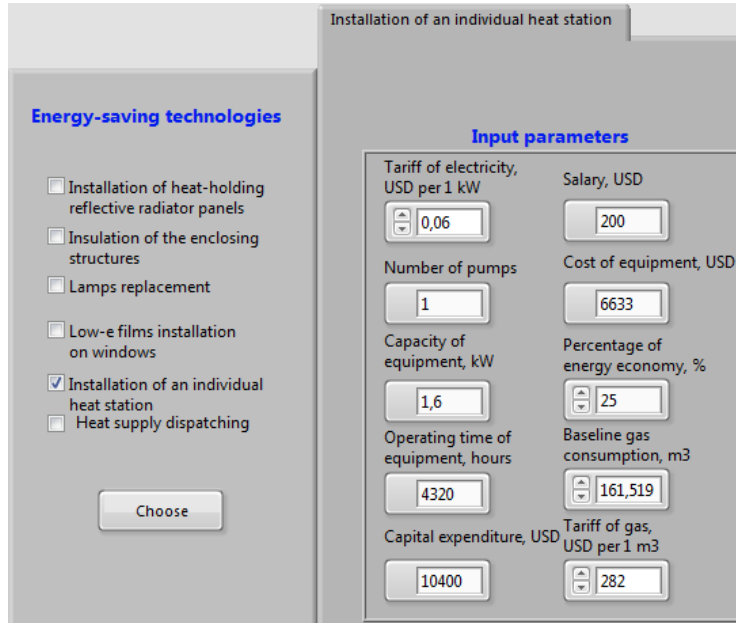

Output parameters

Indicators after implementation

Economy of gas, \% Operating costs, USD

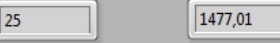

Economy per year,

11387,1

Capital expenditure, USD

10400

Fig. 11. Calculation of indicators of economic efficiency using our own software

Initial data for calculating technical and economic indicators

Table 6

\begin{tabular}{|c|c|c|c|c|c|}
\hline Building & $\begin{array}{c}\text { Internal air tempera- } \\
\text { ture, }{ }^{\circ} \mathrm{C}\end{array}$ & Basic consumption, Gcal & $\begin{array}{l}\text { Basic consumption, } \\
\text { thousand } \mathrm{m}^{3}\end{array}$ & $\begin{array}{l}\text { Capital expenditures, } \\
\text { thousand USD }\end{array}$ & $\begin{array}{l}\text { Operating expenses, } \\
\text { thousand USD }\end{array}$ \\
\hline \multirow{2}{*}{$\mathrm{AB} 1$} & \multirow{2}{*}{18} & 672.5 & 84.7 & \multirow{2}{*}{8} & \multirow{2}{*}{1.3} \\
\hline & & 507.1 & 63.9 & & \\
\hline \multirow{2}{*}{$\mathrm{AB2}$} & \multirow{2}{*}{16} & 288.8 & 36.4 & \multirow{2}{*}{8.5} & \multirow{2}{*}{1.3} \\
\hline & & 178.8 & 22.5 & & \\
\hline \multirow{5}{*}{ AB3 } & \multirow{2}{*}{16} & 1281.9 & 161.5 & \multirow{5}{*}{10.4} & \multirow{5}{*}{1.5} \\
\hline & & 815.1 & 102.7 & & \\
\hline & \multirow{3}{*}{12} & 1140.8 & 143.7 & & \\
\hline & & 617 & 77.7 & & \\
\hline & & 293 & 36.9 & & \\
\hline \multirow{3}{*}{ W1 } & \multirow{3}{*}{18} & 428 & 53.9 & \multirow{3}{*}{8.2} & \multirow{3}{*}{1.3} \\
\hline & & 326.5 & 41.1 & & \\
\hline & & 300.3 & 37.8 & & \\
\hline
\end{tabular}

Economic indicators of modernization of buildings of enterprises with $T_{i n}=18{ }^{\circ} \mathrm{C}$

Table 7

\begin{tabular}{|c|c|c|c|c|c|c|c|c|c|c|}
\hline $\begin{array}{l}\text { Subordination } \\
\text { No. }\end{array}$ & $\begin{array}{l}\text { Heat con- } \\
\text { sumption, Gcal }\end{array}$ & $\begin{array}{l}\text { Capital expendi- } \\
\text { tures, thousand } \\
\text { USD }\end{array}$ & $\begin{array}{l}\text { Equipment } \\
\text { cost, thousand } \\
\text { USD }\end{array}$ & $\begin{array}{c}\text { Operating } \\
\text { expenses, } \\
\text { thousand USD }\end{array}$ & $\begin{array}{l}\text { Savings } \\
\text { percent- } \\
\text { age }\end{array}$ & $\begin{array}{l}\text { Savings, } \\
\text { Gcal }\end{array}$ & $N P V$ & $P I$ & $I R R$ & $D P P$ \\
\hline 1 & 596.1 & 8 & 5.1 & 949 & 25 & 149 & 18.7 & 2.3 & 35.7 & 2.2 \\
\hline 2 & 672.5 & 8 & 5.1 & 949 & 25 & 168 & 22.8 & 2.9 & 44.7 & 1.83 \\
\hline 3 & 181.4 & 4.9 & 2.5 & 468.8 & 40 & 72.6 & 8.1 & 1.7 & 22.6 & 2.8 \\
\hline 3 & 233.3 & 4.9 & 2.5 & 468.8 & 35 & 81.7 & 10.1 & 2.1 & 30.7 & 2.36 \\
\hline 3 & 233.3 & 4.9 & 2.5 & 468.8 & 35 & 81.7 & 10.1 & 2.1 & 30.7 & 2.36 \\
\hline 3 & 855.3 & 10.4 & 6.6 & 1171.9 & 25 & 213.8 & 29 & 2.8 & 43.8 & 1.86 \\
\hline 4 & 173.6 & 4.9 & 2.5 & 468.8 & 40 & 69.4 & 7.4 & 1.5 & 20 & 2.94 \\
\hline 4 & 264.4 & 4.9 & 2.5 & 468.8 & 30 & 79.3 & 9.5 & 1.96 & 28.7 & 2.46 \\
\hline 5 & 225.5 & 4.9 & 2.5 & 468.8 & 35 & 78.9 & 9.5 & 1.94 & 28.3 & 2.47 \\
\hline 5 & 531.3 & 8 & 5.1 & 949 & 30 & 159.4 & 20.9 & 2.6 & 40.7 & 1.96 \\
\hline 5 & 531.3 & 8 & 5.1 & 949 & 30 & 159.4 & 20.9 & 2.6 & 40.7 & 1.96 \\
\hline 5 & 655.7 & 8 & 5.1 & 949 & 25 & 164 & 21.9 & 2.7 & 42.8 & 1.89 \\
\hline 6 & 456.2 & 8 & 5.1 & 949 & 30 & 136.9 & 16 & 2 & 29.5 & 2.42 \\
\hline 7 & 305.8 & 4.9 & 2.5 & 468.8 & 30 & 91.7 & 12.2 & 2.5 & 38.8 & 2 \\
\hline 8 & 150.3 & 4.9 & 2.5 & 468.8 & 40 & 60.1 & 5.4 & 1.1 & 10 & 3.65 \\
\hline 8 & 220.3 & 4.9 & 2.5 & 468.8 & 35 & 77.1 & 9.1 & 1.86 & 26.7 & 2.6 \\
\hline 9 & 476.9 & 8 & 5.1 & 949 & 30 & 143 & 17.4 & 2.2 & 32.7 & 2.3 \\
\hline 10 & 124.4 & 4.9 & 2.5 & 468.8 & 50 & 62 & 5.8 & 1.2 & 12 & 3.5 \\
\hline 11 & 222.9 & 4.9 & 2.5 & 468.8 & 35 & 78 & 9.3 & 1.9 & 27.6 & 2.5 \\
\hline 12 & 259.2 & 4.9 & 2.5 & 468.8 & 35 & 90.7 & 12 & 2.5 & 38 & 2 \\
\hline 13 & 160.69 & 4.9 & 2.5 & 468.8 & 40 & 64.3 & 6.3 & 1.3 & 14.5 & 3.3 \\
\hline 13 & 171.06 & 4.9 & 2.5 & 468.8 & 40 & 68.4 & 7.1 & 1.46 & 18.7 & 3 \\
\hline
\end{tabular}

Note: $N P V$ - net present value; $P I$ - profitability index; IRR - internal rate of return; DPP - discounted payback period 
In projects worth 4.8 thousand USD, the minimum required set of equipment for local automated regulation of heat consumption according to weather conditions was taken into account.

\section{SWOT analysis of research results}

Strengths. The proposed technical solution for an automated system for monitoring temperature conditions and remote control of heat consumption will lead to an optimal level of energy consumption during the operation of buildings and increase the level of safety of people.

Weaknesses. In this study, only one technical solution is considered. The modernization of the existing heating points of a large number of enterprise buildings requires significant capital investments and training of personnel to work with the new equipment.

Opportunities. Further modernization of engineering systems will reduce energy consumption and reduce the cost of products manufactured by the enterprise.

Threats. The declared economic effect can be achieved only in case of correct installation and operation of the equipment.

\section{Conclusions}

1. The analysis of the heat loads of the consumers of the enterprise was carried out, the structure of the distribution of the heat loads of 226 buildings behind the temperature of the internal air was established. More heat load $55 \%$ of the total load falls on heating. The largest consumers at the enterprise ( 49 buildings) are buildings with an internal temperature of $T_{\text {in }}=16{ }^{\circ} \mathrm{C}$. Their load is $26.2 \mathrm{Gcal} / \mathrm{h}(66.1 \%)$. Thirty-two office buildings with $T_{i n}=18{ }^{\circ} \mathrm{C}$ will require the third largest heat load $(10.5 \%)$.

2. Calculations of energy consumption for their heating were carried out for four separate buildings according to aggregated indicators and a detailed methodology. The analysis shows that for the building AB1, the hourly consumption of thermal energy for the expanded methodology is much less than the costs calculated according to the aggregated indicators. This indicates that, according to the detailed methodology, the calculations are more accurate by taking into account the reduced resistance to heat transfer of external opaque wall enclosing structures.

3. The selected scheme of an automated individual heating point with monitoring and control of heat consumption provides an increase in the level of safety of people and bringing to the optimal level of energy consumption during the operation of enterprise buildings. The calculations of the commercial attractiveness of the proposed technical solutions using the improved discounted method indicate the feasibility of their implementation. For example, the technical re-equipment of the heating unit of the building $\mathrm{AB} 1$ at a cost of 8 thousand USD with a base annual heat consumption of 672.5 Gcal will pay off after 1.94 heating seasons with savings of 178.2 Gcal (6.3 thousand USD).

When modernizing 22 selected buildings, it is planned to reduce heat consumption by 2349.4 Gcal. Capital expenditures for the modernization of buildings is 150 thousand USD. The average payback period is 2.47 heating seasons.

\section{References}

1. Zarubizhnyi dosvid z pidoyshchennia enerhetychnoi efektyonosti ta vprovadzhennia novykh tekhnolohii vyrobnytsto a elektrychnoi enerhii (2014). Viddil informatsiino-analitychnoho zabezpechennia zarubizhnoiu informatsiieiu VP NTTsE DP «NEK «Ukrenerho». Kyiv. Available at: https://ua.energy/wp-content/ uploads/2018/01/4.-Efektyvn_vyrobn_elektroenergiyi.pdf

2. Derzhavna sluzhba statystyky. Available at: http://www.ukrstat. gov.ua/

3. Ilin, R. A., Stoliarov, D. V. (2015). Kompleksnaia modernizatsiia teplovykh punktov $\mathrm{v}$ sistemakh tsentralizovannogo teplosnabzheniia. Simvol nauki, 12-1, 42-45.

4. Mironov, N., Petrosova, D. (2015). Economic Efficiency of Automated Individual Heating Substation (IHS). Applied Me chanics and Materials, 725-726, 1285-1291. doi: http:/doi.org/ 10.4028/www.scientific.net/amm.725-726.1285

5. Demirovic, N. (2016). Techniques to Achieve Energy Efficient Heating Substation. ERK'2014, Portorož, A, 205-208. doi: http:// doi.org/10.13140/RG.2.1.4146.7924

6. Vítězslav, M., Havlásek, M. (2016). Integration of Air to Water Heat Pumps into Industrial District Heating Substations. Chemical Engineering Transactions, 52, 739-744. doi: http:// doi.org/10.3303/CET1652124

7. Zvonareva, Y. N., Ziganshin, S. G., Izmaylova, E. V., Gavrilov, A. S., Moryashev, A. V., Kolcun, M. (2019). Efficiency of systems of heat supply with introduction of automated individual heating substations. E3S Web of Conferences, 124, 01026. doi: http://doi.org/10.1051/e3sconf/201912401026

8. Gustafsson, J., Delsing, J., van Deventer, J. (2010). Improved district heating substation efficiency with a new control strategy. Applied Energy, 87 (6), 1996-2004. doi: http://doi.org/10.1016/ j.apenergy.2009.12.015

9. Castro Flores, J. F. (2016). Energetic and exergetic analysis of alternative low-temperature based district heating substations arrangements. International Journal of Thermodynamics, 19 (2), 71. doi: http://doi.org/10.5541/ijot.5000148882

10. Gadd, H., Werner, S. (2013). Heat load patterns in district heating substations. Applied Energy, 108, 176-183. doi: http:// doi.org/10.1016/j.apenergy.2013.02.062

11. Noussan, M., Jarre, M., Poggio, A. (2017). Real operation data analysis on district heating load patterns. Energy, 129, 70-78. doi: http://doi.org/10.1016/j.energy.2017.04.079

12. Perekrest, A. L., Romanenko, S. S., Naida, V. V. (2012). Optymizatsiia protsesu teplopostachannia navchalnoho zakladu. Enerhozberezhennia, enerhetyka, enerhoaudyt, 11 (105), 2-8.

13. Perekrest, A., Khovrak, I., Chebotareva, Ye. (2016). Peculiarities of assessing economic efficiency of implementing energy saving solutions in civil building. Electromechanical and energy saving systems, 2 (34), 124-132.

14. Chebotarova, Ye. (2020). Avtomatyzatsiia rozrakhunku prohnozovanykh pokaznykiv vprovadzhennia enerhozberihaiuchykh rishen. Kontrol $i$ upravlinnia o skladnykh systemakh (KUSS-2020). Available at: http://ir.lib.vntu.edu.ua//handle/ $123456789 / 30638$

$\triangle$ Yevheniia Chebotarova, Postgraduate Student, Department of Automation and Computer-Integrated Technologies, Kremenchuk Mykhailo Ostrohradskyi National University, Kremenchuk, Ukraine, e-mail: yevheniia.ch93@gmail.com, ORCID: https://orcid.org/00000003-4725-7914

Andrii Perekrest, Doctor of Technical Sciences, Associate Professor, Head of Department of Automation and Computer-Integrated Technologies, Kremenchuk Mykhailo Ostrohradskyi National University, Kremenchuk, Ukraine, ORCID: https://orcid.org/0000-00027728-9020

$\bowtie$ Corresponding author 